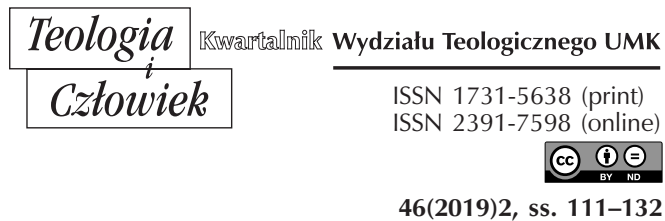

KASPER MARIUSZ KAPROŃ OFM

FACULTAD DE TEOLOGÍA "SAN PABLO"

UNIVERSIDAD CATÓLICA BOLIVIANA - COCHABAMBA (BOLIVIA)

KASPER@KRAKOW.HOME.PL

ORCID: 0000-0002-0054-3414

\title{
LATYNOAMERYKAŃSKI MODEL DUSZPASTERSTWA MŁODZIEŻY
}

DOI: http://dx.doi.org/10.12775/TiCz.2019.018

Streszczenie. W artykule autor, wychodząc od rzeczywistości młodych ludzi w Ameryce Łacińskiej i prezentując dynamikę duszpasterską tamtejszego Kościoła, wskazuje na konieczność zmian w formach Duszpasterstwa Młodzieży. Przedstawia model duszpasterski dla Kościoła wychodzącego na zewnątrz, wpisujący się w szerszy projekt nawrócenia pastoralnego, do którego wzywa papież Franciszek. Postuluje taką reformę struktur eklezjalnych, aby odpowiadały temu, o czym można przeczytać w Dokumencie Końcowym Konferencji w Aparecida: „Kościół wezwany jest do głębokiego i gruntownego przemyślenia swojej misji i rozpoczęcia jej na nowo z wiernością i odwagą w nowej rzeczywistości Ameryki Łacińskiej i świata” (DA 11).

Wymaga to od Kościoła przyjęcia postawy otwarcia na nowe inicjatywy, wspierania działań, które rozwijają się „na zewnątrz”, z dala od środowiska parafii i przyjęcia postawy misyjnej, co wiąże się z koniecznością wyjścia w kierunku „młodzieżowych peryferii”. Oznacza to obowiązek przemyślenia dotychczasowych form funkcjonowania duszpasterstwa, porzucenia gotowych schematów działania, aby móc spotkać młodych tam, gdzie oni rzeczywiście się znajdują, czyli najczęściej z dala od Kościoła.

Słowa kluczowe: młodzież; Duszpasterstwo Młodzieży; Ameryka Łacińska; Kościół „wychodzący”; nawrócenie duszpasterskie. 
Summary. Latin American model of pastoral work with youth for an outward-reaching Church. In this article the author presents certain aspects of pastoral work with youth, describing young people's reality and the dynamic of pastoral work in Latin America, as well as certain aspects of pastoral work with youth for an "outward-reaching" Church. Criteria are indicated for the pastoral accompaniment of Latin American young people today, from a model of Church which Pope Francis has denominated "outward-reaching" (or "going forth"). This model challenges us to rethink pastoral work with youth, situating it in the horizon of the path of pastoral action in the perspective of Aparecida, which allows us to "deeply rethink and relaunch [the Church's] mission in current Latin American and global circumstances with fidelity and audacity" (DA 11).

This requires that the Church show its readiness to appreciate, value and encourage pastoral initiatives and processes that are developing "outside" of explicit parochial spheres, so as to immerse itself in the missionary adventure towards and into spaces where young people are on the margins. Without doubt this means reconsidering the forms in which parochial and wider ecclesial life is organized. This challenge implies leaving behind pre-designed blueprints in order to meet young people there where they are, in the majority of cases outside the Church, adapting to their times and rhythms.

Key words: Youth; pastoral work with youth; Latin America; a Church that "goes forth" (or an "outward-reaching" Church); pastoral conversion.

Resumen. Modelo Latinoamericano de la Pastoral Juvenil para una Iglesia en salida. En el artículo el autor presenta algunos aspectos de la Pastoral Juvenil (PJ), describiendo la realidad juvenil y la dinámica pastoral desde América Latina. Vienen también presentados algunos aspectos de la PJ para una "Iglesia en salida" y se indica los criterios para un acompañamiento pastoral a los jóvenes latinoamericanos hoy, desde el modelo de Iglesia que el papa Francisco ha denominado "en salida" y que nos desafía a repensar la PJ ubicándola en el horizonte de la reforma eclesial que este pontificado viene impulsando. Se trata de buscar e encontrar el camino de la pastoral en la perspectiva de Aparecida, que permita "repensar profundamente y relanzar con fidelidad y audacia la misión [de la Iglesia] en las nuevas circunstancias latinoamericanas y mundiales” (DA 11).

Esto requiere de la Iglesia mostrar su disponibilidad a apreciar, valorar y alentar las iniciativas y procesos pastorales que están en desarrollo "fuera" del ámbito explícito de las parroquias, para insertarse en aventura misionera hacia y dentro de las periferias juveniles y sin duda esto supone un replanteamiento de las formas de organizar la vida parroquial y eclesial más amplia. Este reto exige salir de los propios esquemas pre-confeccionados, para encontrar a los jóvenes allí donde están, es decir en mayoría de los casos fuera de la Iglesia, adecuándose a sus tiempos y a sus ritmos.

Palabras claves: Juventud; Pastoral Juvenil; América Latina; Iglesia “en salida”; Conversión Pastoral. 


\section{WSTĘP}

XV Zgromadzenie Ogólne Synodu Biskupów obradujące wokół tematu „Młodzież, wiara i rozeznawanie powołania”, które odbyło się w Rzymie w dniach od 3 do 28 października 2018 roku, posługiwało się $\mathrm{w}$ pracach metodologią używaną $\mathrm{w}$ teologii latynoamerykańskiej (widzieć - oceniać - działać), która wychodzi od życia, doświadczenia i rzeczywistości ${ }^{1}$. Już w Dokumencie Przygotowawczym zaproponowano uczestnikom Synodu porzucić wszelkie wcześniejsze założenia i wejść w rzeczywistość, w której młodzi ludzie żyją, zrozumieć kontekst społeczny, gospodarczy, polityczny, kulturowy i religijny, w jakim funkcjonują ${ }^{2}$. Wskazano na konieczność otwarcia się na nowość świata ludzi młodych i na potrzebę nabycia umiejętności spoglądania na świat w taki sam sposób, w jaki Jezus patrzył na młodzieńca z Ewangelii: „spojrzał na niego z miłością" (por. Mk 10,21). Otwarcie się na rzeczywisty świat i analiza w świetle kryteriów teologicznych konkretnych potrzeb współczesnej młodzieży, pozwoli wypracować adekwatne do współczesności formy duszpasterskiej działalności.

Celem niniejszego artykułu jest zwrócenie uwagi na konieczność gruntownej reorganizacji Duszpasterstwa Młodzieży. Konieczność zmian

1 Podstawowa metoda używana obecnie przez teologów Ameryki Łacińskiej posiada swoje europejskie korzenie. Wypracowana została przez kard. Josepha Cardijna (1882-1967) i następnie zastosowana jako metoda konfrontacji życia z Ewangelią we francuskim związku Chrześcijańskiej Młodzieży Robotniczej (Jeunesse Ouvrière Chrétienne). Paradygmat, którego istotę wyraża triada: widzieć, ocenić, działać (voir, juger, agir), zyskał akceptację papieża Jana XXIII w encyklice Mater et Magistra (nr 236). Według paradygmatu Cardijna należy najpierw rozpoznać poprawnie zjawisko, które się analizuje, następnie dokonać oceny tego zjawiska w świetle kryteriów teologicznych, aby w końcu z konfrontacji opisu zjawiska i jego oceny wyprowadzić wnioski pastoralne dla aktualnej działalności zbawczej Kościoła. Paradygmat metodologiczny trzech kroków (widzieć, ocenić, działać) znalazł zastosowanie podczas obrad Soboru Watykańskiego II, a szczególnie przy wypracowaniu ostatecznego kształtu Konstytucji duszpasterskiej o Kościele w świecie współczesnym Gaudium et spes.

${ }^{2}$ Dokument przygotowawczy XV Zgromadzenia Ogólnego Synodu Biskupów na temat „Młodzieży, wiary i rozeznania powołania”, http://www.vatican.va/roman_curia/ synod/documents/rc_synod_doc_20170113_documento-preparatorio-xv_it.html (dostęp: 15.05.2019). 
wynika z głębokich przeobrażeń w środowisku młodzieży. W adhortacji apostolskiej Evangelii gaudium (EG) papież Franciszek pisze: „Duszpasterstwo młodzieżowe, tak jak byliśmy przyzwyczajeni je prowadzić, ucierpiało w zderzeniu ze zmianami społecznymi. W zwyczajnych strukturach młodzi często nie znajdują odpowiedzi na swoje niepokoje, potrzeby, problemy i zranienia" (nr 105).

W artykule zastosowano metodę „widzieć - oceniać - działać”: przedstawiona zostaje zatem aktualna sytuacja młodzieży Ameryki Łacińskiej (widzieć); analiza tego środowiska pozwoliła wypracować przez Konferencję Episkopatów Ameryki Łacińskiej i Karaibów (CELAM) Planu Duszpasterskiego do pracy z młodzieżą (działać). Kryteriami teologicznymi, które pomogły w wypracowaniu planu duszpasterskiego, są m.in. Dokument Końcowy Konferencji CELAM w Aparecida oraz nauczanie papieża Franciszka, zwłaszcza adhortacja Evangelii Gaudium (oceniać). W świecie, który jest globalną wioską, refleksja ta, chociaż skontekstualizowana geograficznie, może stanowić inspiracje do podjęcia podobnych działań w odmiennych kontekstach społecznych i geograficznych, w tym dla Kościele w Polsce.

\section{RZECZYWISTOŚĆ MŁODZIEŻY AMERYKI ŁACIŃSKIEJ}

Planując i organizując duszpasterstwo, Kościół musi mieć świadomość ogromnych przeobrażeń w religijności krajów Ameryki Łacińskiej. W ostatnich latach zauważalnym jest zarówno systematyczny proces odchodzenia wiernych od Kościoła katolickiego na rzecz wspólnot protestanckich, jak też proces całkowitego porzucania religii. Dane statystyczne wskazują też, że liczba katolików utrzymuje się na stałym poziomie lub nieznacznie wzrasta w środowiskach osób ekonomicznie i społecznie lepiej usytuowanych. Katolikami generalnie są osoby cieszące się zabezpieczeniem finansowym, mogące poszczycić się zdobytym wykształceniem, stałą pracą i godnymi warunkami mieszkaniowymi. Odsetek ewangelików i członków sekt wzrasta natomiast w środowiskach osób o wysokim wskaźniku ubóstwa, zamieszkujących peryferyjne dzielnice wielkich metropolii (slumsy), bez minimalnego zabezpieczenia socjalnego i bez możliwości zdobycia wykształcenia. W Ameryce Łacińskiej błędny- 
mi zatem okazują się socjologiczne teorie sekularyzacji mówiące o tym, że tradycyjne potrzeby religijne obniżają się w miarę wzrostu dobrobytu społeczeństwa. Związane jest to przede wszystkim z procesem migracji ludności wiejskiej, która przenosząc się do miast, powiększa obszary peryferyjnych dzielnic nędzy. Wykorzenienie ze środowiska i kultury pochodzenia, nierówności społeczne i trudności materialne powodują, że osoby porzucają religię, z której wyrośli. Zaspokojenia potrzeb religijnych szuka się zatem w nowej religii, która może odpowiedzieć na nową sytuację i nowe wyzwania ${ }^{3}$.

To zasadniczo właśnie w miastach mamy do czynienia ze zjawiskiem ekspansji nowych kościołów wywodzących się z tradycji protestanckiej i pentekostalnej, jak również opcjami alternatywnymi, do których możemy zaliczyć m.in. grupy ezoteryczne i praktyki orientalne. Te ostatnie są szczególnie atrakcyjne wśród młodzieży ${ }^{4}$. Panorama religijności w Ameryce Łacińskiej jest obecnie niezwykle dynamiczna, a konwersje i przechodzenie z jednej wspólnoty religijnej do drugiej są zjawiskiem powszechnym i częstym ${ }^{5}$.

Także sytuacja społeczna ludzi młodych jest złożona. Bezrobocie młodych jest poważnym problemem. Pozbawieni zatrudnienia nie tylko nie mają możliwości zdobycia środków celem zaspokajania podstawowych potrzeb materialnych, ale czują się też poniżeni w ludzkiej godności. Ponadto, potęgowana przez reklamę mentalność konsumpcyjna sprawia, że młodzi często wchodzą na drogę przestępczą. Problem narkomanii, alienacji młodych i ich przynależności do grup przestępczych od dawna przestał być problemem marginalnym.

3 N. Somma, M. Bargsted, E. Valenzuela, Cambios en las identificaciones religiosas en América Latina (1995-2010): diagnóstico y explicaciones tentativas. Konferencja wygłoszona w czasie XXIX Kongresu Socjologów Latynoamerykańskich (ALAS), Santiago de Chile 2013. Zob. także: A. Uzeda Vásquez, Los jóvenes y la religión. Vivencias religiosas de jóvenes cristianos en la ciudad de Cochabamba (Bolivia): participación y prácticas en organizaciones religiosas juveniles, Cochabamba 2015, 7.

${ }^{4} \mathrm{M}$. Pereira, Interfaces religiosas en el espacio urbano: análisis escatológico de la complejidad citadina. Konferencja wygłoszona w czasie XXIX Kongresu Socjologów Latynoamerykańskich (ALAS), Santiago de Chile 2013, 43.

${ }^{5}$ O. Nájera, Los nuevos imaginarios religiosos de los jóvenes, "Revista de Antropología Experimental” 7 (2007), 11. 
Świat doznań i przeżyć emocjonalnych ludzi młodych jest jeszcze bardziej złożony. W wielu przypadkach rodzice dbają o dorastające dzieci otaczając je nadmierną troską (nadopiekuńczość), która, będąc formą przemocy, prowadzi do patologii i wywołuje efekt przeciwny do zamierzonego. $\mathrm{W}$ innych przypadkach mamy do czynienia $\mathrm{z}$ całkowitym brakiem dialogu i relacji. Prowadzi to do napięć i konfliktów międzypokoleniowych. Największymi problemami są jednak przemiany w tradycyjnym modelu rodziny, wzrastająca liczba rozwodów oraz liczba dzieci przychodzących na świat $\mathrm{w}$ związkach nieformalnych lub poza jakąkolwiek strukturą rodzinną ${ }^{6}$. Konsekwencje psychologiczne dorastania bez jednego z rodziców lub też będąc wychowywanym przez dziadków, są szeroko analizowane przez specjalistów i truizmem jest stwierdzenie, że dziecko do prawidłowego rozwoju potrzebuje obojga rodziców.

Przedstawiając panoramę środowiska młodzieżowego w Ameryce Łacińskiej, należy wspomnieć także o tych, którzy mieszkają na wioskach i o rdzennej ludności indiańskiej, gdzie do niedawna w ogóle nie istniała młodzież jako osobna grupa społeczna, lecz z dzieciństwa od razu przechodziło się w dorosłość. Obecnie, ze względu m.in. na powszechny obowiązek szkolnictwa, grupa ta już się wykreowała, co nie znaczy jednak, że w środowiskach tych wytworzyły się odpowiednie przestrzenie formacji i uczestnictwa, gdzie młodzi mogliby swobodnie wyrażać swoje pragnienia i oczekiwania.

Ten szkicowo zarysowany obraz środowiska młodzieży w Ameryce Łacińskiej mówi nam, że młodzież jest najsłabszą grupą społeczną i że nie ma jedynej formy bycia młodym. Każdy z nich to indywidualna historia, często utkana $\mathrm{z}$ dramatów i każdą z tych historii należałoby osobno poznać, aby móc zrozumieć, co znaczy być dzisiaj młodym w Ameryce Łacińskiej. „Miejmy uszy nastawione na słuchanie młodzieży - mówił papież Franciszek w katedrze w Rio de Janeiro - Oni potrzebują bycia wysłuchanym. Wsłuchajmy się, co i jak mówią o swoich iluzjach, sukcesach, trudnościach. Trzeba usiąść, słuchając może tej samej piosenki, ale z inną muzyką i z innym natężeniem. Cierpliwości zatem w słuchaniu!

${ }^{6}$ K. Dembicz, Transformacje demograficzne w Ameryce Łacińskiej a postawy prokreacyjne i plany rodzinne latynoamerykańskiej młodzieży akademickiej, Warszawa 2014. 
O to was proszę z całego serca!... Umiejmy tracić czas dla nich"”. Zrozumienie ich historii, ich potrzeb, zmieniających się upodobań, sposobów zachowań i przekonań pozwoli uniknąć błędu, jakim byłoby pragnienie narzucenia na nich postaw i zachowań młodzieży z innego pokolenia (być może naszego, a może nawet wcześniejszego). Taka postawa wyraża się w dyskursach piętnujących i dyskryminujących, a często także obraźliwych ${ }^{8}$. Wyrażenia typu: „to nie jest normalne”, „to tak musi być”, „to nie jest zgodne z naturą" itp. niestety nadal są częścią składową kościelnego języka pragnącego określać to, co jedynie słuszne i „normalne”. Jednakże to, że coś kiedyś zostało uznane za normatywne nie oznacza, że takim musi być już zawsze. Każda ludzka historia jest ukształtowana tu i teraz. Wiele aspektów codziennego życia uznawanych w jednym środowisku za „naturalne” i „normalne”, to nic innego jak zwyczaj, a specyfika zwyczajów polega na tym, że posiadają one swoją historyczną, kulturową i społeczną genezę. Wraz ze zmieniającym się kontekstem historycznym, kulturowym i społecznym, także zwyczaje podlegają zmianom9.

Inicjatywy duszpasterskie wymagają dzisiaj subwersji. Należy odejść od duszpasterstwa zajmującego się jedynie dogmatem i moralnością udręczonego upadkiem Kościoła jako instytucji, który traktowany jest jednocześnie jako jedyny gwarant i interpretator tego, co słuszne, dobre i uniwersalne. Bycie praktykującym katolikiem nie ogranicza się bowiem do znajomości doktryny, nauczenia się norm i zasad postępowania oraz wiernego wypełniania vademecum „dobrego chrześcijanina”. W Kościele potrzebne jest dzisiaj duszpasterstwo, które potrafi wyjść na spotkanie ludziom młodym, doceni ich i zaakceptuje; które patrzy na rzeczywistość z nadzieją, a nadzieję tę czerpie nie ze sztywnych zasad doktryny, lecz $\mathrm{z}$ doświadczenia spotkania z Osobą.

7 Franciszek, Homilia w czasie mszy św. z udziałem biskupów, kapłanów, zakonników i seminarzystów (Rio de Janeiro, 27 lipca 2013 r.), http://w2.vatican.va/content/ francesco/pl/homilies/2013/documents/papa-francesco_20130727_gmg-omelia-rio-clero. html (dostęp: 15.05.2019).

${ }^{8}$ V. Manuel Ruano Pineda, Criterios de una pastoral para los jóvenes de Centro América, "Medellín” 170 (2018) 189-190.

9 A. Fresia, Los jóvenes plurales, representaciones sociales y desafectación institucional, “Medellín” 170 (2018), 141. 
W płynnej i złożonej rzeczywistości, w której młodzi podlegają ciągłym zmianom, błędem jest twierdzić, że już w nic nie wierzą i że nie są w stanie zaakceptować i dostosować się do tradycyjnych form współżycia społecznego. Zadaniem priorytetowym w Kościele powinno być wypracowanie modelu działalności duszpasterskiej w pełni odpowiadającego rzeczywistym potrzebom młodzieży. Niestety, nadal dominującym jest model oparty na języku nakazowo-zakazowym i na normach wyrażonych w postaci gotowych schematów, który jedynie odstrasza lub pokazuje wiarę jako coś anachronicznego, nieadekwatnego do tego, co niesie współczesność z całym jej zawikłaniem, ale też wrażliwością. Duszpasterstwo młodzieży powinno prowadzić do przyjęcia w wolności i odpowiedzialności daru łaski i uczynienia go owocnym, poprzez konkretne i spójne wybory życiowe. ${ }^{10}$ Programowy dokument obecnego pontyfikatu, jakim jest adhortacja Evangelii gaudium (EG), mówi o konieczności nawrócenia duszpasterskiego w kierunku Kościoła wyruszającego w drogę i jest to konkretna wskazówka odnośnie do pracy duszpasterskiej. Kościół, edukując w wierze, powinien mieć odwagę odejść od gotowych schematów i wszelkiego typu gotowych modeli postępowania, na rzecz wypracowywania niestandardowych form pracy, biorących pod uwagę cechy osobiste i sytuacje życiowe młodego człowieka. Nie neguje się potrzeby wypracowania programów duszpasterskich, jednakże same one nie wystarczą. Są użyteczne pod warunkiem, że nie stanowią sztywnych wytycznych do realizacji, lecz służą pomocą $\mathrm{w}$ ewangelizacji młodzieży tam, gdzie ona rzeczywiście się znajduje, to jest najczęściej daleko od Kościoła.

\section{METODOLOGIA APARECIDY: POWOKANI, ABY BYĆ UCZNIAMI - MISJONARZAMI}

Najważniejszym punktem odniesienia w działalności duszpasterskiej Kościoła latynoamerykańskiego jest Konferencja w Aparecida (DA) ${ }^{11}$. Biskupi zgromadzeni w sanktuarium maryjnym w Aparecida „potwierdzili

10 P. Berger. Los numerosos altares de la modernidad. En busca de un paradigma para la religión en una época pluralista, Salamanca 2016, 13.

${ }^{11}$ CELAM, Aparecida. V Ogólna Konferencja Episkopatów Ameryki Łacińskiej i Karaibów, Gubin 2014. 
preferencyjną opcję na rzecz młodych ludzi” oraz wezwali do odnowy i promocji latynoamerykańskiego duszpasterstwa młodzieży, „aby mogło ono odpowiedzieć na rzeczywiste potrzeby tysięcy młodych ludzi, którzy szukają i pragną w Kościele odnaleźć przestrzeń czynnego uczestnictwa”" ${ }^{12}$. W Ameryce Łacińskiej, zgodnie z Dokumentem z Aparecidy, dynamizm Duszpasterstwa Młodzieży zawiera się w słowach: „powołani, aby być uczniami - misjonarzami”. Bycie uczniem i misjonarzem to dwa nierozłączne wymiary chrześcijańskiego powołania. Osobiste spotkanie z Jezusem prowadzi bowiem do misji. Kiedy uczeń pozna i pokocha swojego Pana, doświadcza potrzeby dzielenia się radością spotkania $\mathrm{z}$ innymi. Odkrywa w sobie powołanie, aby głosić Jezusa Chrystusa, kochać Go i służyć Jemu w osobie najbardziej potrzebujących.

Bycie uczniem - misjonarzem jest procesem, którego punktem wyjścia jest pozwolić znaleźć się Jezusowi. Spotkanie z Nim prowadzi do nawrócenia i do pójścia za Nim we wspólnocie Kościoła (por. DA 278). Całe chrześcijańskie życie, powołanie i misja muszą być naznaczone osobistym spotkaniem z Jezusem. „U początku bycia chrześcijaninem przypomina Benedykt XVI - nie ma decyzji etycznej czy jakiejś wielkiej idei, jest natomiast spotkanie z wydarzeniem, z Osobą, która nadaje życiu nową perspektywę, a tym samym decydujące ukierunkowanie"13. Dlatego też Kościół, jeśli chce przyciągnąć młodych, musi zaoferować im przestrzeń spotkania. Chrystus nie jest bowiem ideą lub wiedzą, której można nauczyć się, lecz jest Osobą, która ma moc nadać sens całej egzystencji. Kiedy projekt Jezusa zostaje przyjęty przez młodego człowieka, to staje się on projektem życiowym, projektem przeżywanym i realizowanym we wspólnocie Kościoła. „Tylko ktoś prawdziwie zakochany w Chrystusie może zmienić swoje otoczenie"14.

Duszpasterstwo Młodzieży staje się „teofanią”, kiedy pozwala młodemu człowiekowi odzyskać naturalną wrażliwość i pomaga mu przejść od egzystencjalnej pustki do wiary, od indywidualizmu i obojętności, do zaangażowania, od człowieka „bez powołania” do człowieka, który od-

12 P. Castilleja de León, El Modelo de la Pastoral Juvenil Latinoamericana, "Medellin” 144 (2010), 67.

13 Benedykt XVI, Deus caritas est, 1.

${ }^{14}$ CELAM, Documento Conclusivo del II Congreso Continental Latinoamericano de Vocaciones (Cartago - Costa Rica, 30 de enero al 5 de febrero de 2011), 61. 
krywa, że jest wezwanym. Teofania staje się „teopatią”, gdy młoda osoba doświadcza tego, że Bóg cierpi z tymi, którzy cierpią i wzywa do służenia ${ }^{15}$, gdy młody człowiek odkrywa, że znajduje się „,w szpitalu polowym” - używając sformułowania papieża Franciszka - i zaczyna współczuć rannym. Dzieląc się własnym życiem, odkrywa, że prawdziwy sens życia tkwi w ofiarowywaniu siebie innym ${ }^{16}$. Duszpasterstwo młodzieży powinno doprowadzić do sytuacji, kiedy to młodzi posługując np. w dzielnicach nędzy i widząc dramat najuboższych, zakwestionują siebie i zaczną stawiać sobie pytanie: Co mogę zrobić z moim życiem? O co mnie prosi Bóg? Do czego On mnie wzywa?

Zadaniem Duszpasterstwa Młodzieży jest zatem pomagać młodym w odkrywaniu świata rzeczywistego: „Zobaczcie, jaki jest kraj i jaki lud w nim mieszka. [...] Jaka jest ziemia, urodzajna czy nie?” (Lb 13,18-20). Duszpasterstwo Młodzieży ma stopniowo wprowadzać młodych w doświadczenie obecności Boga w konkretnych sytuacjach życia i pomóc $\mathrm{w}$ rozeznaniu przez nich powołania. Ma sprzyjać okryciu Jezusa i podjęciu decyzji pójścia za Nim, rozeznaniu działania Ducha Świętego w znakach czasu i w historii osobistej, wspólnotowej, eklezjalnej i społecznej oraz podjęciu radykalnej decyzji życia zgodnego z Ewangelią.

\subsection{NOWE POSTAWY MILLENIALSÓW}

Wielu młodych ludzi jest już zmęczonych kulturą konsumpcyjną i dominującym w świecie modelem gospodarczym, który tworzy konsumentów. Zmęczenie zanurzeniem w płynnym społeczeństwie ponowoczesności ${ }^{17}$, otwiera drogę ku formom życia kreatywnego wypracowanym niemalże od podstaw i będącym niczym nasiona nowych sposobów życia, alternatywnych do świata znormalizowanego przez powszechny indywidualizm.

${ }^{15}$ C. Silva Guillama, Vocación y discernimiento en la vida de los jóvenes, "Medellín” 170 (2018) 168-169.

16 CELAM, Documento Conclusivo del II Congreso Continental Latinoamericano de Vocaciones (Cartago - Costa Rica, 30 de enero al 5 de febrero de 2011), 71-74.

17 Z. Bauman, Ponowoczesność jako źródło cierpień, Warszawa 2000. 
Zauważalnym jest fakt, że wśród tzw. millenialsów i under-29 pokolenia digital natives i Facebooka - dokonuje się obecnie proces przekonfigurowania wartości. Zjawiska, które dla poprzednich pokoleń wydawały się marginalne lub nieistotne, stają sie dla współczesnej młodzieży priorytetami: kwestia ochrony środowiska i jakość relacji międzyludzkich, otwartość na przybysza i uciekiniera, pytania o rolę państwa $z$ równoczesnym odrzuceniem etatyzmu. Tolerancja ze względu na rasę, wyznawaną religię, orientację seksualną jest powszechną wartością. Młodzież pokolenia Erasmusa i lotów low-cost, przynależąca do świata, który jest globalną wioską, bardzo chętnie angażuje się w różnego rodzaju formy wolontariatu i jest niezwykle wyczulona na problematykę ubóstwa, kryzysu ekologicznego, przestępczości wśród rówieśników, braku równouprawnienia i wykorzystywania kobiet. Spotykamy się z różnymi formami zaangażowania, nawet tymczasowego, celem rozwiązywania konkretnych problemów społecznych, co prowadzi do zaangażowania na rzecz budowy społeczeństwa obywatelskiego ${ }^{18}$.

W osiedlowych świetlicach i klubach akademickich gromadzi się młodzież zainteresowana własną historią i próbująca zrozumieć złożoną sytuację społeczno-polityczną współczesności. Możemy mówić o zjawisku upolitycznienia młodzieży, która na poważnie pragnie interesować się zmianami, jakie dokonują się w społeczeństwie, chociaż swojej przyszłości nie chce już wiązać z partiami politycznymi. Młodzież ta jest bowiem wyczulona na polityczną propagandę i rozczarowana zarówno korupcją tego środowiska, jak i brakiem skutecznych form przeciwdziałania zjawiskom takim jak terroryzm, przemoc wobec kobiet, bezrobocie młodzieży, rabunkowa gospodarka niszcząca środowisko naturalne. Wielu młodych ludzi odczuwa silne pragnienie bycia dawcą życia i to nie w znaczeniu ściśle biologicznym, lecz przede wszystkim jako tych, którzy przywracają sens życia tym, którzy go zagubili. Młodzi starają się budować głębokie relacje z rówieśnikami i pomagać im odkryć, że prawdziwe szczęście polega nie na potęgowaniu własnego ego, lecz na byciu osobą generatywną: zdolną dać życie, poświęcając siebie ${ }^{19}$.

${ }_{18}$ Na przykład strona internetowa www.generativita.it, ukazuje przykłady aktywności społecznej młodzieży we Włoszech i w świecie.

19 C. Castillo Mattasoglio, Una pastoral de Juventud a 50 años de Medellín: entre 


\subsection{JESTEŚMY GATUNKIEM BĘDĄCYM W CIĄGŁEJ PODRÓŻY}

Globalizacja, migracje całych grup społecznych i narodów, swoboda podróży międzykontynentalnych otwierają młodych ludzi na nowy świat. Są oni dziś wędrowcami - niczym pielgrzymujący lud Starego Testamentu - poszukującymi ziemi obiecanej: szczęścia, pełni życia, Boga. Postawa pielgrzyma, który ciągle jest $\mathrm{w}$ drodze i nie posiada na ziemi nic stałego jest tą, z jaką łatwo identyfikują się, zarówno w wymiarze indywidualnym, jak też społecznym i religijnym. Stąd też odrzucenie wszelkich form zinstytucjonalizowanych praktyk religijnych (pozorny ateizm młodzieży), jak i istniejących modeli życia społecznego (brak afiliacji). Są osobami w ciągłym ruchu, z łatwością zmieniającymi przynależność religijną, społeczną i kulturową. Wielkie religie jednak zawsze wysoko ceniły symbol drogi i bycie pielgrzymem. Powinniśmy na nowo zdefiniować, czym powinno być prawdziwe duszpasterstwo migracji, turystyki i pielgrzymek: powinno ono wskazywać kierunek tym wszystkim, którzy poszukują sensu życia i transcendencji ${ }^{20}$.

Mobilność współczesnej młodzieży wykracza jednak zdecydowanie poza rzeczywistość fizyczną i przemieszczanie się z jednego geograficznego miejsca w drugie. Są oni przede wszystkim wędrowcami w cyberprzestrzeni. Grupy społeczne na ulicy i w sieci, spotkanie na placu i na ekranie, kontakt z rówieśnikami poprzez dotyk i poprzez \#hastag są dla młodych tymi samymi formami spotkania, gdyż nie istnieje dla nich rozróżnienie na świat rzeczywisty i wirtualny ${ }^{21}$. Dla młodych ludzi nie ma podwójnej obecności (fizycznej i wirtualnej), a formą przekraczania bariery przestrzeni celem spotkania się i bycia razem w takim samym stopniu może być samochód (lub inny środek komunikacji) jak i komputer. Jeśli Kościół pragnie być dzisiaj w świecie młodych wędrowców i poszukujących pielgrzymów, musi zacząć wędrować wraz z nimi. Inaczej będzie skazany na porażkę.

liberación y regeneración. Konferencja wygłoszona w czasie V spotkania teologów latynoamerykańskich, Bogotá 2018, 19.

${ }^{20}$ I. Ariel Fresia, Jóvenes errantes y declive de la pastoral. Hacia nuevas perspectivas de pastoral con jóvenes, Buenos Aires 2016, 38.

${ }_{21}$ R. Reguillo, Paisajes insurrectos. Jóvenes, redes y revueltas en el otoño civilizatorio, México 2017, Chiara Giaccardi, Jóvenes, medios digitales y desafíos educativos, “Misión Joven” 66 (2016) 95-100. 
Rzeczywistość świata wirtualnego miesza się zatem ze światem realnym i ten pierwszy przychodzi z pomocą i służy drugiemu. Zdjęcia opublikowane w sieci, zwłaszcza gdy są dramatyczne, rozpowszechnione w grupach tworzonych przez młodych ludzi, nawet satyryczne memy odzwierciedlające np. głupotę klasy politycznej, pomimo że to wszystko rodzi się z koncepcji rzeczywistości jako obrazu filmowego, budzą w użytkownikach Internetu świadomość, że nie można uczestniczyć w życiu tylko poprzez kliknięcie „lubię to” lub „udostępnij”, lecz należy wyjść na ulicę i krzykiem wyrazić siebie. Masowe manifestacje (np. w Polsce zarówno inicjatywa „Różaniec bez granic”, jak i „Czarne Protesty”, w Boliwii grupy 21F przeciwko reelekcji Evo Moralesa na urząd prezydenta) - ujawniły wzrost zaangażowania społecznego młodych i potęgę mediów społecznościowych.

\subsection{POWOŁANIE UCZNIÓW-MISJONARZY}

Wezwanie Aparecidy do bycia uczniem-misjonarzem jest zatem odpowiedzią zarówno na problemy współczesności, jak też na wewnętrzne aspiracje i dążenia młodego człowieka. Zadaniem uczniów-misjonarzy jest bowiem ukazać w sposób aktywny swoją obecność w świecie, współpracując ze wszystkimi, którzy pragną budować cywilizację życia. Przejawia się to w działaniach podejmowanych na rzecz najuboższych, potrzebujących i uciskanych, w walce ze wszystkimi formami zła, korupcją i niesprawiedliwością. Dotyczy to także działań podejmowanych na rzecz troski o wspólny dom całej ludzkości, jakim jest Planeta Ziemia ${ }^{22}$.

Poprzez formy aktywności misyjnej zainspirowane osobą Jezusa, kształtuje się "nowy podmiot w historii, którego nazywamy uczniem” (DA 243): aktywny członek Kościoła i obywatel o świadomości globalnej, wywierający wpływ na społeczeństwo w wymiarze politycznym, kulturowym i ekonomicznym. Duszpasterstwo Młodzieży nie polega zatem na dyskutowaniu, lecz na działaniu realizowanym we wspólnocie Kościoła, aby oświecić światłem Jezusa Chrystusa rzeczywistość ludzi potrzebu-

${ }^{22}$ V. Manuel Ruano Pineda, Criterios de una pastoral para los jóvenes de Centro América, “Medellín” 170 (2018), 198. 
jących. Aparecida ukazuje model Kościoła, który pragnie naśladować Jezusa Chrystusa (bycie uczniem) oraz podejmuje się zadania głoszenia Ewangelii (wymiar misyjny). Kościół „wychodzący” jest tym, który służy życiu i wywiera wpływ na społeczeństwo.

\section{MOŻLIWE OBSZARY AKTYWNOŚCI DLA DUSZPASTERSTWA MŁODZIEŻY}

Konferencja Episkopatów Ameryki Łacińskiej i Karaibów (CELAM) w czteroletnim programie duszpasterskim, na lata 2015-2019²3 wskazała kilka obszarów misji ewangelizacyjnej, które mogą stanowić przestrzeń działań Duszpasterstwa Młodzieży Kościoła „wychodzącego na zewnątrz".

\subsection{SPRAWIEDLIWOŚĆ SPOŁECZNA W KONTEKŚCIE WIELKICH NIERÓWNOŚCI}

Ameryka Łacińska nadal jest kontynentem wielkich nierówności społecznych. Wzrost ekonomiczny jest chwiejny, liberalna gospodarka promowana przez kolejne rządy powiększa jedynie dysproporcje pomiędzy niewielką grupą ludzi bogatych a ogromną rzeszą ubogich. Duszpasterstwo Młodzieży, które nie zaangażuje się w działaniach na rzecz sprawiedliwości społecznej skazane jest na porażkę, gdyż brak mu będzie zakorzenienia w konkretnej rzeczywistości. Katolickie Duszpasterstwo Młodzieży nie może być zatem „ukrytą pokusą ucieczki w miejsce bezpieczne, które może mieć wiele imion: indywidualizm, spirytualizm, zamknięcie w małych światach, powtarzanie utrwalonych schematów, dogmatyzm, nostalgia, pesymizm, uciekanie się do zasad" (Gaudete et exsultate, 134). Opcja na rzecz ubogich i działania na rzecz sprawiedliwości to tematy ciągle aktualne i nie przynależą one jedynie do Kościoła inspirującego się teologią wyzwolenia ${ }^{24}$.

${ }^{23}$ CELAM, Plan Global 2015-2019, Bogotá 2015, http://www.celam.org/documentos/Plan_Global_y_Programas_2015-2019.pdf, (dostęp: 15.05.2019).

24 Por. tamże, 21. 
Kościół „wychodzący na zewnątrz”, o którym mówi papież Franciszek, musi ciągle na nowo podejmować działania na rzecz sprawiedliwości społecznej. Działania te należy podjąć z determinacją, bez lęków i chłodnych kalkulacji, które mogą jedynie ugasić profetyczny żar ewangelicznej pracy. Podejmowane wysiłki na rzecz sprawiedliwości społecznej sprawią, że staniemy się bliscy ludziom ubogim, którzy działania te będą postrzegać jako konkretne gesty solidarności w ich codziennych zmaganiach o przezwyciężenie biedy i niesprawiedliwości ${ }^{25}$.

\section{2. "TROSKA O NASZ WSPÓLNY DOM"}

Papież Franciszek w encyklice Laudato si’ prezentuje fundamentalną kwestię dla współczesnego świata, czyli troskę o zachowanie środowiska naturalnego. Rabunkowa gospodarka surowcowa wyrządzająca niepowetowane szkody w zasobach naturalnych i w konsekwencji prowadząca do zmian klimatu, jest wyzwaniem dla całych społeczeństw i otwiera przestrzeń działania Duszpasterstwa Młodzieży angażującego się w kształtowanie wśród młodych ludzi świadomości troski o świat przyrody „jako dziedzictwo, które otrzymaliśmy, aby je chronić, gdyż stanowi bezcenną przestrzeń ludzkiego współistnienia i jest miejscem, w którym uwidacznia się odpowiedzialność człowieka nad powierzonym mu dobrem"26.

Jeśli pragniemy tworzyć zaangażowane Duszpasterstwo Młodzieży, to należy opracować programy edukacyjne kształtujące odpowiedzialność ekologiczną, promujące prawa Ziemi i alternatywne formy pozyskiwania energii. Wspólnie z młodymi należy podejmować kroki na rzecz budowy „społeczeństwa ekologicznego”, kształtując nawyki, które doprowadzą do zmian $\mathrm{w}$ dotychczasowym stylu życia naznaczonym mentalnością konsumpcyjną. W wymiarze ściśle religijnym należy promować wśród młodych ludzi chrześcijańską duchowość ekologiczną ${ }^{27}$.

${ }^{25}$ Por. Carta de los Presbiteros a las Comunidades Eclesiales de Guatemala con motivo de su Encuentro Nacional (31.07 - 2.08. 2017), n. 6.

${ }^{26}$ CELAM, Plan Global 2015-2019, 23.

27 Cfr. Franciszek, Laudato si', 210-211. 


\subsection{BUDOWANIE POKOJU W ŚWIECIE NAZNACZONYM PRZEMOCA}

Duszpasterstwo Młodzieży powinno dążyć do budowania pokoju, gdyż pokój jest Dobrą Nowiną Jezusa. W społecznościach, takich jak latynoamerykańskie, mamy jednak do czynienia z ogromną skalą przemocy i stałego zagrożenia życia. Ofiarami przemocy są głównie ludzie młodzi i to oni też tworzą grupy przestępcze. Spośród młodzieży wywodzą się zarówno ofiary przestępstw, jak i ich sprawcy, tworząc złożoną rzeczywistość peryferyjnych osiedli wielkich miast.

Formy przestępczości są różnorodne: działania zbrojnych gangów młodzieżowych, kradzieże i rozboje z bronią w ręku, które sprawiają, że poruszanie się $\mathrm{w}$ godzinach wieczornych i nocnych po osiedlach, zwłaszcza peryferyjnych, jest niebezpieczne. Zatrważającymi są dane dotyczące przemocy domowej, której ofiarami są kobiety i dzieci. Wymownym jest fakt, że w języku hiszpańskim istnieje odrębne słowo feminicidio określające morderstwo kobiet.

Biorąc pod uwagę cały ten kontekst oraz mając świadomość niebezpieczeństw, jakie niesie ze sobą dojrzewanie w środowisku przemocy i przestępczości, działania na rzecz pokoju są jednym z najważniejszych wyzwań stojących przed Duszpasterstwem Młodzieży. Byłoby błędem ze strony Kościoła promować duszpasterstwo, w którym nie podejmie się tak ważnego wyzwania, które dotyczy społeczeństwa, gdzie „ciągle mają miejsce konflikty i mamy do czynienia ze wzrostem przestępczości w postaci kradzieży, rozbojów, porwań, a przede wszystkim tych najokrutniejszych zbrodni, jakim są morderstwa, które niszczą życie i zanurzają w bólu rodziny i całe społeczeństwa"28.

\subsection{PROBLEM MIGRACJI W RZECZYWISTOŚCI ZUBOŻENIA}

Ameryka Łacińska jest regionem, gdzie miliony osób zmuszonych jest do emigracji, zarówno wewnętrznej (ze wsi do miast), jak i zewnętrznej (do innego kraju). „Przyczyny emigracji są różnorodne, związane są jednak przede wszystkim z sytuacją gospodarczą i polityczną, przemocą,

${ }^{28}$ CELAM, Plan Global 2015-2019, 26. 
ubóstwem, brakiem perspektyw i poszukiwaniem lepszych warunków życia"29.

Grupą, na którą w analizie problemu migracji należy zwrócić szczególną uwagę, są mieszkańcy wsi i rdzenni mieszkańcy kontynentu, którzy emigrując, zmuszeni są porzucać środowisko, w którym przyszli na świat. Emigracja prowadzi do wykorzenienia: osoby tracą oparcie, jakie posiadali w rodzimych tradycjach i kulturze, a osiedlając się na peryferyjnych dzielnicach wielkich miast, czują się całkowicie zagubieni, nie tylko w wymiarze ekonomicznych, lecz przede wszystkim tożsamościowych. Prowadzi to w konsekwencji do przestępczości, alkoholizmu i narkomanii, szczególnie wśród młodego pokolenia. Należy także wspomnieć o wstydliwych i dramatycznych zjawiskach, związanych z problemem migracji, jakimi są handel ludźmi, prostytucja, turystyka seksualna, w tym wykorzystywanie nieletnich ${ }^{30}$.

Kościoły lokalne, poprzez Caritas, starają się pomagać materialnie i duchowo tysiącom imigrantów. Podejmowane są też różnorodne działania pomocowe (np. dotyczące integracji ludności napływowej poprzez tworzenia świetlic i klubów, gdzie ludność napływowa mogłaby kultywować rodzime tradycje). Dla młodzieży działającej w duszpasterstwach, zaangażowanie na rzecz imigrantów staje się przestrzenią formacji w podwójnym wymiarze: chrześcijańskim i społeczno-obywatelskim, ponieważ „wartością, jakie niesie ze sobą zjawisko migracji, jest wymiana kulturowa pomiędzy społecznościami i narodami, hybrydyzacja społeczeństwa oraz uczenie się dojrzałego współżycia społecznego"31. Zjawisko migracji należy zatem wykorzystać celem jeszcze większego zaangażowania młodzieży w Kościoły partykularne, gdyż „Kościół i społeczeństwo obywatelskie przywiązują dziś wielką wagę do międzykulturowości i powszechności, i coraz liczniejsze instytucje pragną ratować piękno i specyfikę poszczególnych społeczności i narodów, kultywując i promując ich różnorodne formy ekspresji kulturowej" 32 .

\footnotetext{
29 Tamże, 28

30 Tamże, 29.

31 Tamże, 30.

32 Tamże.
} 
Te cztery płaszczyzny działania otwierają nowe perspektywy dla Duszpasterstwa Młodzieży, które pragnie być autentycznie misyjne i „wyjść na zewnątrz” w kierunku peryferii geograficznych, kulturowych i egzystencjalnych współczesności. Konkretne formy zaangażowania na rzecz ochrony środowiska, przeciwdziałania przestępczości, wyrównywania dysproporcji społecznych i pomocy migrantom, to działania mające na celu współtworzenie „Kościoła autentycznie ubogiego, misyjnego i paschalnego", który wychodzi, aby głosić światu radość Ewangelii. Tylko wtedy, gdy młody człowiek zaangażuje się w pracę na rzecz drugiego człowieka, dotkniętego ubóstwem i samotnością, będzie mógł zmierzyć się $\mathrm{z}$ „wielkim ryzykiem dzisiejszego świata, z jego wieloraką i przygniatającą ofertą konsumpcji", który to świat, chociaż to ukrywa, to jednak przeżywa „smutek rodzący się w przyzwyczajonym do wygody i chciwym sercu”. Zniechęcenie i brak chęci do życia, zarzucane często ludziom młodym, to właśnie efekt zamykanie się we własnych interesach, w świecie, gdzie nie ma już miejsca dla innych, nie liczą się ubodzy, nie słucha się już więcej głosu Bożego, nie doświadcza się słodkiej radości z Jego miłości, a w konsekwencji zanika entuzjazm związany z czynieniem dobra" (por. EG 2).

Nie ulega wątpliwości, że przemyślenie Duszpasterstwa Młodzieży w takiej perspektywie jest zadaniem. Młodzi ludzie na pewno pełniej jednak utożsamiać się będą z Kościołem, który jest „domem otwartych drzwi”; który przyjmuje wszystkich bez uprzedzeń, który jest pełnym prostoty „domem i szkołą komunii” emanującym ciepłem, bliskością i promującym „kulturę spotkania”. W Kościele „miłosiernym jak Ojciec” młodzi ludzie poczują się przyjęci z radością, a następnie współodpowiedzialni i wezwani do misji, gdyż pierwsi na sobie odczują bliskość matczynych wnętrzności, które odzwierciedlają miłosierdzie Boga.

\section{ZAKOŃCZENIE}

Wszystko to, co zostało przedstawione powyżej, to jedynie teoretyczne ramy Duszpasterstwa Młodzieżowego dla „Kościoła wyruszającego w drogę”. Biskupi Ameryki Łacińskiej, którzy opracowali ten program, są jednak przekonani, że Duszpasterstwo Młodzieży, aby mogło właściwie realizować swoją misję edukacyjną i formacyjną, nie może dłużej 
funkcjonować jako grupy refleksji, lecz musi podjąć konkretne działania w rozwiązywaniu ważnych społecznie problemów. Podejmowane działania (np. czuwania modlitewne, nocne pielgrzymki do sanktuariów, otwarte debaty dotyczące ważnych dla regionu problemów, uczestnictwo w manifestacjach, zbiórki na rzecz potrzebujących itd.) rozbudzają w młodych osobach przekonanie, że życie jest misją i kiedy młodzi traktują życie jako misję, to staje się ono szkołą wzrostu i rozwoju.

Pojęcie „misja” w tym znaczeniu nie odnosi się jednak do każdej misji, lecz jedynie do tej, która prowadzi do kontemplacji Jezusa z Nazaretu. Chodzi bowiem o misję, która pomaga poznać Jezusa, żyć Jego życiem i świadczyć o obecności Tego, który swoje życie uczynił misją. Ci wszyscy, którzy w szczerości swego serca szukają Go i pragną dla siebie i dla swoich bliźnich pełni człowieczeństwa, muszą w końcu spotkać się i skonfrontować z osobą Jezusa. Duszpasterstwo Młodzieży jest autentycznym, jeśli ukazuje prawdziwe oblicze Jezusa, tak jak przedstawia Go Ewangelia. Niestety, dla wielu, szczególnie ludzi młodych, Jezus z Nazaretu pozostaje „wielką niewiadomą”. W hiperreligijnym społeczeństwie, jakim jest nasze, dominują karykatury Jezusa. Często używa się Jego imienia, lecz pozostaje nieznanym. Wymownymi są słowa francuskiego filozofa, Rogera Garaudy: „Ludzie Kościoła, oddajcie nam Jezusa!”. Być może należałoby się przyznać, że to właśnie Kościół, ze swoim strukturami, rytuałami, kapłanami..., jest odpowiedzialnym za to, że ludzie nie poznali Chrystusa. To właśnie Kościelne struktury przejęły całkowicie Jezusa, zamknęły go w formułach doktryn, w prawie i w rytuałach, czyniąc Go dalekim i niezrozumiałym. Dlatego też słowa Jezusa z Ewangelii św. Marka nabierają nowego znaczenia: „Nikt nie trzyma nowego wina w starych bukłakach ... Nowe wino, do nowych bukłaków” (Mk 2,21-22).

Zadanie Duszpasterstwa Młodzieży można porównać z misją Jana Chrzciciela: wskazać na Jezusa i pomóc młodym ludziom, aby poszli za Nim. W społeczeństwie, gdzie doktryny już nie przyciągają, a emocje są kruche i tymczasowe, należy tak zreorganizować Duszpasterstwo Młodzieży, aby konkretne zaangażowanie kwestionowało młodego człowieka i rodziło w nim podstawowe pytania o sens życia: Skąd pochodzimy? Czego pragniemy? Dokąd zmierzamy?

Duszpasterstwo Młodzieży, stawiając jako wzór do naśladowania Jezusa Chrystusa, powinno motywować młodych ludzi do działań na 
rzecz każdego człowieka, szczególnie ubogiego i odrzuconego. Ma być procesem włączającym młodych w dzieło ewangelizacji. Ewangelizować znaczy bowiem czynić to samo, co czynił Jezus: słowem i czynem głosić i urzeczywistniać przyjście Królestwa Bożego. Jest to Królestwo życia, które zakłada wyzwolenie ze śmierci i z wszelkich form zniewolenia (por. DA 359, 361). Ewangelizacja tak rozumiana jest integralną, jej najważniejszym celem nie jest to, aby zwiększała się liczba katolików, lecz jest aktem służenia światu. Jest to ewangelizacja, która zakłada opcję preferencyjną na rzecz ubogich, integralną promocję człowieczeństwa oraz autentyczne chrześcijańskie wyzwolenie (por. DA 146). Realizując tak postawione cele, Duszpasterstwo Młodzieży sprzyja budowaniu nowego stylu życia wśród młodzieży: prostego, skromnego, solidarnego, ekologicznego.

Reorganizacja Duszpasterstwa jest bez wątpienia także wyzwaniem dla samych duszpasterzy, gdyż domaga się porzucenia dawnych schematów i wyjścia do ludzi młodych tam, „gdzie [oni] przebywają, dostosowując się do ich czasu i rytmu, traktując ich na poważnie z problemami jakie przeżywają, pomagając im w odkrywaniu rzeczywistości w której żyją i próbując przekazać im orędzie za pomocą gestów i słów, w codziennym ich wysiłku budowania własnej historii i w poszukiwaniu, mniej lub bardziej świadomie, sensu życia”33. Nie można już dalej utrzymywać dawnego modelu Duszpasterstwa zamkniętych grup spotykających się głównie po to, aby podyskutować i całkowicie zależnych od duszpasterza, która to forma nie sprzyja „wychodzeniu na zewnątrz”, negując tym samym możliwość, aby młodzi ludzie „z odwagą wypłynęli na głębokie wody, w kierunku nieznanej, lecz obiecującej przyszłości, którą sam Bóg przed nimi otwiera" 34 .

\section{BIBLIOGRAFIA}

Bauman Zygmunt, Ponowoczesność jako źródło cierpień, Warszawa 2000. Benedykt XVI, Encyklika Deus Caritas Est (25.12.2015).

${ }^{33}$ Dokument przygotowawczy XV Zgromadzenia Ogólnego Synodu Biskupów na temat „Młodzieży, wiary i rozeznania powołania”.

${ }^{34}$ Franciszek, List do młodych z okazji prezentacji Dokumentu przygotowawczego XV Zgromadzenia Ogólnego Synodu Biskupów, 13 stycznia 2017. 
Berger Peter, Los numerosos altares de la modernidad. En busca de un paradigma para la religión en una época pluralista, Salamanca 2016.

Castilleja de León Patricia, El Modelo de la Pastoral Juvenil Latinoamericana, „Medellín” 144 (2010), s. 58-71.

Castillo Mattasoglio Carlos, Una pastoral de Juventud a 50 años de Medellín: entre liberación y regeneración. Konferencja wygłoszona w czasie $\mathrm{V}$ spotkania teologów latynoamerykańskich, Bogotá 2018.

CELAM, Aparecida. V Ogólna Konferencja Episkopatów Ameryki Łacińskiej i Karaibów, Gubin 2014.

CELAM, Documento Conclusivo del II Congreso Continental Latinoamericano de Vocaciones, Cartago - Costa Rica 2011.

CELAM, Plan Global 2015-2019, Bogotá 2015.

Dembicz Katarzyna, Transformacje demograficzne w Ameryce Łacińskiej a postawy prokreacyjne i plany rodzinne latynoamerykańskiej młodzieży akademickiej, Warszawa 2014.

De Zárate Jesús González, Un Sínodo desde, con y para los jóvenes. Acercamiento a su temática y dinámica desde el lenguaje, las opciones y los movimientos pedagógicos de la Pastoral Juvenil Latinoamericana y Caribeña, „Medellín” 170 (2018), s. 109-130.

Franciszek, Adhortacja Apostolska Evangelii gaudium (24.11.2013).

Franciszek, Adhortacja Apostolska Gaudete et exsultate (19.03.2018).

Franciszek, Encyklika Laudato sì (24.05.2015).

Franciszek, Homilia w czasie mszy św. z udziałem biskupów, kapłanów, zakonników i seminarzystów, Rio de Janeiro, 27 lipca 2013 r.

Franciszek, La Gracia de Dios no es ideología, La Civiltá Cattolica Iberoamericana (https:// www.civiltacattolica-ib.com/la-gracia-no-es-una-ideologia/).

Franciszek, List do młodych z okazji prezentacji Dokumentu przygotowawczego XV Zgromadzenia Ogólnego Synodu Biskupów, 13 stycznia 2017.

Fresia Iván Ariel, Los jóvenes plurales, representaciones sociales y desafectación institucional, „Medellín” 170 (2018), s. 131-158.

Fresia Iván Ariel, Jóvenes errantes y declive de la pastoral. Hacia nuevas perspectivas de pastoral con jóvenes, Buenos Aires 2016.

Giaccardi Chiara, Jóvenes, medios digitales y desafíos educativos, „Misión Joven” 66 (2016), s. 95-100.

Guillama Carlos Silva, Vocación y discernimiento en la vida de los jóvenes, „Medellín” 170 (2018), s. 159-184.

Nájera Ozziel, Los nuevos imaginarios religiosos de los jóvenes, "Revista de Antropología Experimental" 7 (2007), s. 5-36.

Pereira Miguel, Interfaces religiosas en el espacio urbano: análisis escatológico de la complejidad citadina. Konferencja wygłoszona w czasie XXIX Kongresu Socjologów Latynoamerykańskich (ALAS), Santiago de Chile 2013.

Reguillo Rossana, Paisajes insurrectos. Jóvenes, redes y revueltas en el otoño civilizatorio, México 2017. 
Ruano Pineda Víctor Manuel, Criterios de una pastoral para los jóvenes de Centro América, „Medellín” 170 (2018), s. 185-224.

Sekretariat Synodu Biskupów, Dokument przygotowawczy XV Zgromadzenia Ogólnego Synodu Biskupów na temat „Młodzieży, wiary i rozeznania powołania”.

Somma Nicolás - Bargsted Matías - Valenzuela Eduardo, Cambios en las identificaciones religiosas en América Latina (1995-2010): diagnóstico y explicaciones tentativas. Konferencja wygłoszona w czasie XXIX Kongresu Socjologów Latynoamerykańskich (ALAS), Santiago de Chile 2013.

Uzeda Vásquez Andrés, Los jóvenes y la religión. Vivencias religiosas de jóvenes cristianos en la ciudad de Cochabamba (Bolivia): participación y prácticas en organizaciones religiosas juveniles, Cochabamba 2015. 